\title{
The Process is the Punishment: The Case of Bail in New South Wales
}

\author{
Tracey Booth and Lesley Townsley*
}

\begin{abstract}
Bail is a most crucial stage of pre-trial procedure for accused persons who are presumed to be innocent. In the context of bail, punitive crime policies in New South Wales have led to the gradual erosion of the presumption in favour of bail in relation to many offences, the conflation of bail conditions and penalty and a steady increase in the number of persons being held as prisoners on remand. Continuing this punitive turn in crime policy, the Bail Act 1978 (NSW) was recently amended by the Bail Amendment Act 2007. It is the amendment in respect of $\mathrm{s} 22 \mathrm{~A}$, and in particular the resultant changes to the configuration of bail, that is the subject of this article. It is our contention that $\mathrm{s} 22 \mathrm{~A}$ is ill thought out and without sufficient empirical foundation. In the absence of a rational base for this law-making, it can be characterised as a blatant 'get tough' on crime, law and order strategy that has become all too common.
\end{abstract}

\section{Introduction}

At about the same time that the NSW Bail Act was first drafted and enacted (in 1978-1980), Malcolm Feeley published his seminal work, The Process is the Punishment. It was his contention that in the lower courts (where the bulk of criminal matters are dealt with) the pre-trial stage of the criminal process was the primary punishment rather than the adjudication, plea bargaining or the sentence itself (Feeley 1979:30). Feeley argued that certain pre-trial features of the legal process including pre-trial detention, bail, repeated court appearances and forfeited wages could be so onerous for the accused that those costs outweighed penalties imposed later in the process (Feely 1979:15). In other words, those costs shifted 'the locus of sanctioning away from the formal stages of adjudication and sentencing onto the process' (Feeley 1979:30). In our view this theme that the process is punishment is echoed in the current bail law in NSW. As we note below, the increasing punitiveness of crime policies has effectively reduced an accused person's entitlement to bail with adverse repercussions for many. Far from being an instrument used to balance the accused person's entitlement to liberty with the community's well-being, bail can be characterised as sanction in the pre-trial process.

Bail is a most crucial stage of pre-trial procedure for accused persons who are presumed to be innocent. A grant of bail is the difference between being at liberty to enjoy opportunities associated with ordinary citizenship and being held on remand - imprisoned denied most of those opportunities, while awaiting resolution of the matter which could take

University of Technology, Sydney. We would like to thank the anonymous reviewers for their very thoughtful feedback and also, Cathy Anderson, UTS law librarian, for her research support. Any errors remain our own. 
months or even years. In NSW, bail for both juveniles and adults is regulated by the Bail Act 1978 where bail is defined as an 'authorisation to be at liberty under this Act instead of in custody'. ${ }^{1}$ As originally conceived, the Bail Act sought to balance the presumTption of innocence and the entitlement to liberty of an unconvicted person against the needs to ensure that the accused appeared in court and the community was protected.

Almost since the Act commenced operation in 1980 (primarily to assist disadvantaged accused persons to obtain bail), punitive reconfigurations of criminal justice processes have dominated the political agenda. The punitive turn in contemporary crime policy has been well documented, particularly in the areas of mandatory minimum penalties, truth in sentencing, harsher penalties, increasing prison populations, paedophile registers, civil detention and zero tolerance policies (see Garland 2001; Brown 2005; Pratt 2000; Grabosky 1999). In the context of bail, punitive crime policies have led to the gradual erosion of the presumption in favour of bail in relation to many offences, the conflation of bail conditions and penalty (Freiberg \& Morgan 2004; Edney 2007) and a steady increase in the number of persons being held as prisoners on remand. As can be seen below, improvement in the administration of criminal justice has been put forward as the basis of most of these amendments.

Continuing this punitive turn in crime policy, the Bail Act was amended by the Bail Amendment Bill 2007 and the provisions came into effect on 14 December 2007. Together with a further expansion of the list of offences for which there is a presumption against bail, these amendments entered different terrain by establishing limits to the number of bail applications that can be made by an accused to any court under s22A. Hitherto only the number of bail applications that could be made to the Supreme Court had been so limited. It is the latter amendment in respect of s22A, and in particular the resultant changes to the configuration of bail, that is the subject of this article.

Essentially s22A now limits an accused to one bail application in any court with respect to an offence unless:

- the person was not legally represented when the previous application was dealt with, and the person now has legal representation; or

- the court is satisfied that new facts or circumstances have arisen since the previous application that justify the making of another application.

There are two primary reasons given by the government for introducing this limitation. First, that it will prevent 'magistrate shopping' by cashed up accused persons, ${ }^{2}$ and, second, to limit the worry and anxiety of victims of crime at the prospect of the accused being able to make limitless bail applications without merit. The first reason can be characterised as an attempt to improve the efficiency of the administration of the criminal justice system in line

Bail Act 1978 (NSW) s4. For the purposes of bail, juveniles are subject to the Bail Act in the same manner as adult offenders. In addition, s6 of Children (Criminal Proceedings) Act 1987 sets out principles that a court exercising criminal jurisdiction with respect to children is to have regard to. Some of these principles specifically relate to children and bail including (c) 'that it is desirable, wherever possible, to allow the education or employment of a child to proceed without interruption'.

2 The terms 'magistrate shopping' and 'cashed up' have been used repeatedly by the Attorney General John Hatzistergos. In his second reading speech (New South Wales Legislative Council 2007:2669) the Attorney General refers to 'magistrate shopping' as 'the process of going from magistrate to magistrate, or judge to judge, with hope of obtaining a different outcome' and 'cashed up' as meaning an 'accused person with access to money who can fund ongoing legal representation'. Thus, a cashed up accused can engage in magistrate shopping. 
with previous amendments. The latter concern for the plight of victims of crime, however, arguably introduces a new factor in relation to bail - the feelings (rather than safety) of the crime victim.

It is our contention that $\mathrm{s} 22 \mathrm{~A}$ is ill thought out non-rational law making and without sufficient empirical foundation. Despite the rhetoric of crime victims' interests, it can be characterised as a blatant 'get tough on crime' policy that has become all too common in recent years. The provision represents a significant encroachment upon an accused person's entitlement to bail that is not dependent upon the nature of the offence, the circumstances of the accused or even the potential danger to victims and/or the community. In undermining fundamental principles such as the presumption of innocence, the government did not refer to research findings, nor did it indicate inadequacies in the existing s32 criteria or the conditions available under the Act to protect crime victims and others affected by an alleged offence. This is particularly interesting given the following statements of the NSW Attorney-General, Mr Hatzistergos in July 2007 when discussing the tightening of bail presumptions:

Deprivation of liberty is a serious consequence, particularly for someone who has not been found guilty...

Thousands of bail decisions are made every day and I am proud to say that in the vast majority of cases the right decision is made (Daily Telegraph 26/7/2007).

This article is divided into three parts. The first part sets out the legal context within which s22A operates, provides a brief history of bail laws in NSW, including the enactment of the Bail Act 1978 (NSW), and includes an overview of three decades of change in bail law and process. In the next part, we analyse s22A including an examination of the provision itself, a comparison of similar law in Victoria and a discussion of the adverse repercussions already being felt in the criminal justice system. In the final part, we address the prominence of the symbolic, political crime victim in punitive crime policies and conclude that provisions such as s2 A do not adequately address the heterogeneity of victims' interests while undermining fundamental criminal justice principles.

\section{Bail in New South Wales}

\section{A Common Law Tradition}

Bail is an ancient institution of the criminal process. Historically a grant of bail operated to release the accused into the custody of a surety who was then completely responsible for the accused while on bail (Simpson 1997:3). The modern concept of bail is that of a right afforded to a person charged with a criminal offence to be released from official custody subject to an undertaking that he or she return to a court as directed. Such a grant of bail may be unconditional or conditional.

Prior to legislative reform in 1978 , laws relating to bail were located in various statutes and common law principles and, according to the Australian Law Reform Commission, 'badly in need of overhaul' (Simpson 1997:7). In 1976 the NSW Government established the Bail Review Committee to appraise the existing bail laws (Simpson 1997:6). According to that committee, it was 'difficult to overstate the importance of bail' in the criminal process:

At every stage of the often slow progress from arrest to trial and sentence, someone must decide whether the accused will be allowed to continue his normal life while awaiting the next step, or 
whether he must be held in custody. Every decision involves balancing the right to liberty of someone who is legally presumed to be innocent against the need of society to ensure that accused people are brought to trial (Simpson 1997:7).

Particularly problematic for an accused before the emergence of the Bail Act was the prevalence of financial conditions attached to a grant of bail (Simpson 1997:8). Indeed there was no clear common law or statutory authority for the courts to impose non-financial bail conditions. Imposition of 'money bail' however, had a discriminatory effect on those who could not afford large sums of money to meet such bail conditions and as a result, impecunious accused were heavily represented in the number of prisoners held on remand (Brignell 2002:1). Simpson notes that before the commencement of the Bail Act, bail hearings generally lasted less than two minutes and in most cases no information about the accused was presented to the court and no attempt was made to assess any special circumstances of the accused to the ability of the accused to meet bail' (1997:8). The Bail Review Committee noted the successful Manhattan Bail Project established in the United States in 1961. This project found a positive correlation between the court verifying information relating to the accused's community ties, a higher rate of release on bail and lower incidence of failing to appear in court. The Bail Review Committee recommended that monetary conditions be reduced in importance and the accused's community ties should be a factor relevant to the determination of bail (Simpson 1997:8). This reasoning reflected what was regarded as a significant purpose of bail - to secure the reappearance of the accused person in court as required.

Following the review, the Bail Act 1978 (NSW) commenced operation in March 1980. In its original form, the Bail Act was designed to balance the community concern for safety against the right to liberty of an accused person presumed to be innocent until proven guilty (Simpson 1997:7). In his second reading speech for the Bill the then Attorney-General clearly articulated the conflicting interests:

Although it is perfectly true that the community must be protected against dangerous offenders, one must not lose sight of the circumstances, first, that when bail is being considered, one is confronted with an alleged crime and an unconvicted accused person, and second, that the liberty of the subject is one of the most fundamental and treasured concepts in our society (NSW Parliamentary Debates 14/12/78:2020 cited in Simpson 1997:8).

\section{The Legislative Framework}

A multi-tiered and complex system of entitlement to bail has been established under the NSW Bail Act. Depending upon the nature of the charge and/or the circumstances of the accused, arrested persons might:

- have a right to bail (s8);

- have a presumption in favour of bail ( $\mathrm{s} 9$ );

- have no presumption in favour of bail (ss9, 9A, 9B);

- have a presumption against bail (ss8A-8F);

- need to establish exceptional circumstances to be granted bail (ss9C, 9D).

If granted bail, the person is entitled to remain at liberty in respect of that offence until required to appear in a court according to his or her bail undertaking (Bail Act 1978 (NSW) s7). In circumstances where the police do not grant bail after the accused is charged with an offence, the accused must be brought before a court as soon as practicable to determine the question of his or her bail (Bail Act 1978 (NSW) s20). 
When considering applications for bail the court is required to take into account the criteria set out in $\mathbf{s} 32$ of the Act. Originally the criteria encompassed three broad areas - the probability that the accused will appear in court, the interests of the accused and the protection and welfare of the community. A fourth area was added in 1987 - the protection of crime victims and other persons affected by the offence. These criteria are exhaustive and the court cannot take account of any other factors in its determination. Unless bail is necessary to promote law enforcement, protect crime victims or other affected persons, protect the community or reduce the likelihood of the commission of future offences by promoting the rehabilitation of the accused, bail should be granted unconditionally (Bail Act 1978 (NSW) s37(1)). If conditions are regarded as necessary by the court, then the conditions attached to the grant of bail should be no more onerous than required given the offence, the welfare of affected persons and the accused's circumstances (Bail Act 1978 (NSW) s37(2)). Financial conditions should only be imposed if no other conditions are likely to promote effective law enforcement, to protect the community and affected persons or to promote the rehabilitation of the accused (Bail Act 1978 (NSW) s37(3)). Bail conditions can be imposed on the accused person or can involve a third person, commonly referred to as a 'surety' and described as an 'acceptable person' in the legislation (Bail Act 1978 (NSW) s36(2)).

Bail can be granted at any stage during the criminal proceedings in respect of the offence of which the person has been charged and/or convicted (Bail Act 1978 (NSW) s6). The power of courts to review bail decisions is governed by provisions in Part 6 of the Act.

\section{Three Decades of Change}

Since it commenced operation in 1980, the Bail Act has been amended on a number of occasions revealing conflicting trends. As noted above, a distinctive punitive theme has been the erosion of the presumption in favour of bail for many offences (Bail Act 1978 (NSW) ss9A, 9B). That degree of erosion is clearly illustrated by $\mathrm{s} 9 \mathrm{~B}(3)$ which provides that there is now no presumption in favour of bail 'in respect of the grant of bail to a person accused of an indictable offence if the person has been previously convicted of one or more indictable offences (whether dealt with on indictment or summarily)'. The list of offences for which there is a presumption against bail has also expanded and a new tier of eligibility introduced whereby an accused will only be granted bail in respect of particular offences if exceptional circumstances justify the grant of bail. ${ }^{3}$

The second reading speeches supporting these amendments indicate that most were incorporated into the Act to improve the administration of criminal justice or to specifically protect the community or persons affected by the offence. Frequently controversial because of a lack of empirical foundation, the amendments have been described as a result 'of political imperatives or moral outrage over a particularly abhorrent high profile case, rather than responses to detailed empirical research or evidence' (Brignell 2002:10-11). What is not in doubt, however, is that, as a result, the number of persons held in remand has steadily increased as entitlement to bail gradually has been squeezed over the years. As the AttorneyGeneral has previously indicated, the number of persons held on remand has increased dramatically over the last three years. He has acknowledged that 'there is no doubt that the inmate population, particularly those on remand, has risen considerably as a result' of

Section 9C murder; section 9D applicant is accused of serious personal violence offence and has been convicted of a serious personal violence offence. 
changes made to the Bail Act to extend the presumption against bail to serious and repeat offenders (New South Wales Legislative Council 2007:2669).

In 2002, bail headed in a new, controversial direction when the Bail Act was amended to provide the accused with opportunities for rehabilitation, treatment or restorative justice as a condition of bail. By virtue of $\mathrm{s} 36 \mathrm{~A}$, bail conditions requiring the accused person to participate in an intervention program can be imposed where the decision-maker is of the opinion that the accused would benefit from participation in one or other of these programs. The three-fold aims of this provision seem to be to: secure the attendance of the accused in court, prevent reoffending by the accused; and ensure the rehabilitation and reformation of the accused (Edney 2007:101). Edney has described such bail conditions as 'therapeutic' and designed to have a favourable impact on the accused in respect of the underlying problems that led to the accused's involvement in the criminal process in the first place. Such an approach is a feature of an emerging 'therapeutic jurisprudence' where the role of the court is intended to be more interventionist to achieve goals outside the traditional criminal justice paradigm.

While such conditions are clearly a shift from tough law and order policies to a more therapeutic realm, other commentators have been concerned that nonetheless such a shift may undermine the traditional concept of bail (Freiberg \& Morgan 2004). Freiberg and Morgan argue that the imposition of a 'rehabilitation' condition blurs the lines between guilt, conviction and sentence because it is both a bail condition and a sentence. In their view such non-traditional bail conditions "provide the legal foundation for serious and relatively long-term interventions that are normally the province of the sentencing courts' (2004:220). They argue that bail should be about the effective running of the criminal process - ensuring that the accused attend court as directed - rather than a means of imposing obligations on an accused 'in order to provide a new basis for future decisions' (2004:234). Thus, whilst superficially such developments can be regarded as therapeutic, in reality further encroachments on the unconvicted accused can also be a feature of the more familiar punitive turn of contemporary crime policy.

Inconsistent with punitive trends in crime policy, however, have been those amendments to the Bail Act acknowledging the special needs of crime victims and particular groups of accused including Indigenous Australians and the mentally ill (see Johns 2002). These amendments reflect governmental recognition of the discriminatory impact of bail provisions and practices on disadvantaged groups. For instance in 1987 the criteria under s32 were expanded to take account of the protection of the victims and other persons affected by the offence (Bail Act 1978 (NSW) s32(1)(b1)). More recently, in 2002, the criteria in section 32 were again expanded to take account of the special needs of children, Aboriginal people or persons who are mentally ill or who have an intellectual disability (Bail Act 1978 (NSW) s32(1)(b)(v)).

\section{Analysis of Section 22A}

\section{Section $22 A$}

Under the original Bail Act, there was no restriction on the number of times an accused person could apply for bail to any court. The number of bail applications that could be made to the Supreme Court was first restricted in 1989 when s22A was inserted into the Act. By virtue of this provision, the Supreme Court was given power to decline to hear repeated bail 
applications unless the court was satisfied that there were 'special circumstances' to justify a further application for bail. At the time the amending Bill was introduced into Parliament, the then Attorney-General justified the amendment on the basis that it was necessary 'to assist the Government's commitment to reducing court delay [by] relieving the obligation of the Supreme Court to entertain meritless applications' (New South Wales Legislative Assembly 1989:7329). Thus the original basis for limiting the number of bail applications to the Supreme Court was a perceived need to improve the efficient administration of criminal justice.

As amended in December 2007, s22A of the Bail Act 1978 (NSW) now extends the limitation on the number of bail applications that an accused can make to any court, not just the Supreme Court. It provides that:

(1) A court is to refuse to entertain an application for bail by a person accused of an offence if an application by person in relation to that bail has already been made and dealt with by a court, unless:

(a) the person was not legally represented when the previous application was dealt with, and the person now has legal representation, or

(b) the court is satisfied that new facts or circumstances have arisen since the previous application that justify the making of another application.

(2) A court may refuse to entertain an application in relation to bail if it is satisfied that the application if frivolous or vexatious.

Together with restricting the number of bail applications that can be made to any court, the provision also places constraints on the conduct of lawyers in this regard. Sub-section (5) provides:

If a court has previously dealt with an application for bail for a person accused of an offence, a further application to a court for bail in relation to that offence may not be made by a lawyer on behalf of that person, unless the lawyer is satisfied that:

(a) the person was not legally represented when the previous application was dealt with, or

(b) new facts or circumstances have arisen since the previous application that justify the making of another application.

As noted in the introduction, s22A has been incorporated into the Act to deal with 'magistrate shopping' and to 'guard against repetitive bail applications that have no chance of success and can greatly disturb the victim and induce worry and anxiety at the prospect of the defendant's release' (New South Wales Legislative Council 2007:2669). During the course of his second reading speech, the Attorney-General boasted that NSW sported the toughest bail laws in Australia and, indeed, this provision in limiting the number of bail applications that an accused can make to a court is unique amongst Australian jurisdictions. Aside from Victoria, no other Australian jurisdiction restricts the number of bail applications that can be made by an accused to any court other than on the grounds that the application is vexatious or frivolous. It is interesting to compare the NSW provisions with those of the Victorian Bail Act 1977 particularly since the Victorian legislation was reviewed by the Victorian Law Reform Commission (VLRC) in 2007.

\section{The Situation in Victoria}

The restrictions on the number of bail applications that can be made in relation to an offence are not as onerous in Victoria. In that jurisdiction, s18(4) of the Bail Act 1977 provides as follows: 
Where application is made under subsection (1) or (6B) to a court in respect of an order made by a court or a bail justice, the first-mentioned court shall not proceed to hear the matter of the application unless the applicant was not represented by a legal practitioner when the order was made or the applicant satisfies the court hearing the application that new facts or circumstances have arisen since the making of the order.

Sub-section (1) provides that where an accused person has been remanded because bail is refused, that person may apply to the court for bail or an order seeking to vary any conditions that might have been attached to a grant of bail. In the event a person's bail is revoked, that person may apply to the court for bail under sub-section (6B). Thus, in Victoria, once an accused person has applied for bail he or she must demonstrate that 'new facts or circumstances have arisen' before a court will hear a further application for bail. Unlike the current law in NSW, however, this restriction in the Victorian legislation does not apply where the accused was not legally represented at previous bail hearings - in other words there is no restriction on the number of bail applications that can be made by unrepresented accused persons. In its report on a review of the Victorian Bail Act, the VLRC explained that 'this exception recognises the disadvantage self-represented applicants often face because of a lack of legal or other skills' (Victorian Law Reform Commission 2007:108). In a footnote, the VLRC refers to research findings whereby "prisoners are less likely to have completed high school than the general population, and they have poor cognitive functioning, limited literacy skills and poor numeracy' (109, fn 106).

The justification for the Victorian approach is similar to that provided by the NSW government. In its consultation paper, the VLRC said that the provision was intended to prevent repeated unmeritorious applications and the practice of 'magistrate shopping'. Submissions to the VLRC indicated that the legislation has led to the practice of lawyers advising clients against legal representation for their bail application shortly after arrest because more time would be needed to prepare a well supported application which could then be presented to the court by a lawyer. As noted in its report, preparation for a bail application often involves organising various reports, character references, character witnesses, accommodation, support services and perhaps sureties. If the accused is legally represented but the application is ill-prepared and bail is subsequently refused, the accused cannot make a further application legally represented unless he or she can establish that 'new facts or circumstances' have arisen. Interestingly, the VLRC noted that submissions were divided as to whether s18 operated as a substantial barrier to justice. The Victorian Magistrate's Court expressed the view that 'the current situation is artificial and can lead to unjust situations ... representation should always be encouraged, as it assists both the applicant and the court' (Victorian Law Reform Commission 2007:108). In particular, the VLRC pointed out that legal representation can also reduce the risk of accused people inadvertently prejudicing their defence if they appear in person.

\section{Ultimately however the VLRC recommended that}

[g]enerally the new facts and circumstances should continue to apply. However the new Bail Act should stipulate that an accused may be represented at a bail application made within two court-sitting days after arrest without having to show new facts or circumstances on a subsequent application (Victorian Law Reform Commission 2007:108).

\section{Repercussions}

The new s22A was part of a bundle of amendments introduced into Parliament in October 2007. According to the Attorney-General, the amending legislation was designed to 'to strengthen our bail laws and ensure that the community is properly protected while defendants are awaiting trial'. The intended effect of these and other recent amendments 
was to ensure that particular types of offenders would 'have a much tougher time being granted bail under our rigorous system' (NSW Legislative Council 2007: 2669).

Yet again, the presumption against bail was extended this time to include additional firearm offences. These additional offences include those connected with a prescribed person involved in a firearms dealing business which attracts a 14-year imprisonment penalty (Firearms Act 1996 (NSW) s44A) and the offence of shortening arms which attracts a 10-year imprisonment penalty (Firearms Act 1996 (NSW) s62). According to the Attorney-General, it was appropriate to include these offences under s8B of the Bail Act to ensure that the legislation was "consistent with regard to serious firearms offences of similar gravity' (NSW Legislative Council 2007:2669). Although there was no research cited in support of the necessity of the amendment, presumably it can be understood as an attempt to protect the community. As the Attorney-General has said previously:

Clearly the more serious the offence the more difficult the obtaining of bail should be. This is not because of a need for immediate sanction but rather because of the need to manage any risks associated with the liberty of the accused (Daily Telegraph 26/7/07).

The consequences of the amendment to $\mathrm{s} 22 \mathrm{~A}$ in the law have already been felt keenly amongst juvenile accused. According to the Public Defender's Office, increasing numbers of juveniles are being held on remand (Haesler 2008). As a consequence, the Children's Detention Centres are full; for instance at the Baxter Juvenile Detention Centre, there have been allegations that juveniles are sleeping in the gymnasium and the visits room and also doubling in single occupancy cells. Long-term juvenile detainees, who have been kept in juvenile detention centres because of their special rehabilitation needs, are being transferred to adult correctional centres (Haesler 2008).

Even prior to the amendment limiting bail applications it was recognised that bail refusal or imposing harsh bail conditions could 'have a particularly punitive effect on young people' (NSW Law Reform Commission 2005:[10.1]). The removal of the right to legal representation for a repeat bail application adds another punitive effect for young people in particular, who will, in general, have a reduced capacity to advocate on their own behalf. Unlike other facets of the criminal justice system which treat young people separately from adults, the Bail Act applies equally to both. ${ }^{4}$ Initially this was viewed as giving young people the same rights as adults in relation to bail, presumably in relation to the discretion to impose other conditions apart from financial sureties. Subsequently there has, however, been little or no recognition in the legislation of the different needs of adults and young people to be at liberty, let alone the discriminatory impacts that this will have on young people.

Apart from the possibility of an accused being transferred to adult correctional centres, several other punitive aspects have been identified in relation to the refusal of bail for young people including:

- whether they progress further into the system rather than being diverted from it,

- the effect of bail refusal upon the content and severity of sentence,

4 But note the amendments introduced by the Evidence (Audio and Audio Visual Links) Amendment Bill 2007 (NSW). Currently, the Evidence (Audio and Audio Visual Links) Act 1998 (NSW) contains separate provisions in relation to young people; this will change when the Bill comes into effect so that the Act will apply to both young people and adults equally. The Bill introduces a presumption in favour of using audio visual links for procedural matters such as bail hearings, sentencing hearings and committal proceedings. These provisions commenced on 1 January 2009. 
- the effect of bail refusal upon an 'interim sentence', or

- the consequences of the imposition of harsh conditions such as curfews, area restrictions or non-association orders (NSW Law Reform Commission 2005:[10.3]$[10.7])$.

Recognition of these punitive effects led the NSW Law Reform Commission to make recommendations such as amending s32 of the Bail Act 'to include separate bail criteria for young people that include the existing criteria and incorporate the principles set out in s6(b)(d) of the Children (Criminal Proceedings) Act 1987 (NSW)' (NSW Law Reform Commission 2005:[10.2]). This recommendation has not been put into effect, and the operation of $\mathrm{s} 32$ without separate criteria in combination with the effects of $\mathrm{s} 22 \mathrm{~A}$ has led to the consequence that young people more than ever have a harder time obtaining and remaining on bail.

In a seminar presented to the NSW Criminal Defence Lawyers Association in April 2008, senior public defender Andrew Haesler SC noted that the adult population of prisons in NSW of 9,749 prisoners on 23 March 2008 was a new record. At this time there were 2,456 people on remand and on average, over 50 remanded and sentenced prisoners were being kept overnight in police cells. However, increasing numbers of people on remand does not seem to be a problem for the government; indeed the Attorney-General has expressed some pride in the increasing prison population and proudly speaks of plans to build more prisons to house the increasing population (Hatzistergos 17 October 2007 Second reading speech, NSW Legislative Council 2007: 2669).

As the Attorney-General has previously indicated, the number of persons held on remand has increased by $20 \%$ over the last three years and further 'from 1995 to 2005 bail refusals in the District Court and Supreme Court have almost doubled, with an increase from 25.8\% to 46.4\%' (New South Wales, Legislative Council 2007:2669). The Attorney-General has attributed these increases in the remand population to tough bail laws that 'crack down on repeat offenders' and remove the presumption in favour of bail for certain serious offences. According to the Australian Bureau of Statistics the increase in the remand population among adult prisoners is a national trend. Although at 30 June 2007, the proportion of unsentenced prisoners was $22 \%$ and this was unchanged since 2006 , there was an increase of $9 \%$ in the total number of unsentenced prisoners in that year (Australian Bureau of Statistics 2007). Additionally, the Australian Institute of Criminology reports at 30 June 2006 remanded prisoners accounted for $22 \%$ of the total prison population compared to $12 \%$ in 1984, and that between 1984 and 2005 the rate of remanded prisoners more than tripled from 10 to 35 per 100,000 of the population (Dearden \& Bricknell 2007:83-84).

What is the effect of being held on remand? It is not simply a matter of finding more short-term accommodation for inmates and building new prisons. Findings of adverse and even catastrophic effects as a result of the denial of bail have been well documented (NSW Bureau of Crime Statistics and Research 1984:4-5) ${ }^{5}$ and continue to be issues today (see Hampel \& Gurvich 2003; King et al. 2008). In July 2007, the Attorney-General said that 'the fact that a person does or does not get bail will not affect the final determination of guilt of innocence that, will, in the end, be made by a court' (Daily Telegraph 26/7/07). However, this reassurance does not sit comfortably with existing research findings.

Where the authors cite studies conducted between 1967 and 1979 discussing the adverse consequences of bail refusal. 
There are many documented problems for those held on remand significantly that remand prisoners have a disproportionately high rate of deaths in custody. The NSW Metropolitan Remand and Reception Centre has reported that the centre's rate of deaths in custody has declined from 1.03 deaths per 100 inmates in 1997/98 to nil deaths in 2006/07 financial years and that the death rates in NSW are generally declining (Hollero 2007:8). However, Joudo and Veld (2005) found that while the deaths of remand prisoners are trending slightly downwards, they remain consistently higher than sentenced prisoners (see discussion in Sarre et al. 2006:2). There are also issues about the conditions and effects of being on remand including the psychological and physical deprivations related to incarceration, together with being deprived of an income and employment and effects on family and dependants (Kelkar 1998:121). Additionally, some persons may be convicted but not sentenced to imprisonment and compensation is not paid to people held on remand who are subsequently acquitted.

While on remand prisoners often have limited access to means of communication, legal assistance and the ability to contact witnesses and to prepare a defence. Additionally, refusal of bail and the reasons for refusal 'will affect impressions of the accused at trial, and the eventual determination of the sentencer' (Findlay et al. 2005:117). Studies show that persons held on remand as a result of the denial of bail are more likely to be convicted than those granted bail as well as more likely if convicted to suffer longer sentences (NSW Bureau of Crime Statistics and Research 1984:4-5; King et al. 2008:336). According to Weatherburn et al.:

As long as the possibility exists that bail refusal may itself increase the risk of conviction or more severe sentence, bail decisions are inextricably linked with the defendant's prospects of a fair trial. Tampering with the presumption in favour of bail when the evidence does not justify it is unwarranted tampering in effect with the defendant's chances of a fair trial (1987:108).

Arguably, restricting the number of bail applications that can be made to a court by an accused also has the potential to interfere with an accused's right to a fair trial.

In its consultation paper, the VLRC expressed concern that if the restriction in s18 was removed 'the system could be flooded with repeat bail applications' (2005:62). Given this potential, the VLRC was of the view that 'there needs to be some form of check on the number of applications brought before the courts although it also acknowledged that it may also do a disservice to accused persons if lawyers are discouraged from acting for accused in such circumstances' (2005:62). This argument seems to suggest concern with costs and an efficient administration of justice but there is no empirical evidence cited from those Australian jurisdictions that do not have similar restrictions on the number of bail applications that can be made by an accused to a court to support it.

The repercussions are not limited to accused people; there are also some significant issues to consider in relation to legal practitioners. Section $22 \mathrm{~A}(5)$ now imposes a statutory duty on lawyers to desist from making a further application for a bail refused person unless the lawyer is satisfied that the person was not previously represented or that there are new facts or circumstances that justify the making of another application. What are the implications of this?

First, the duty is analogous to the undertakings of lawyers in the civil system to certify that a cause of action has reasonable prospects of success. It is likely that criminal lawyers will be subject to professional misconduct or unsatisfactory professional conduct if they breach the duty. Whilst requiring these undertakings may reduce the number of bail 
applications being heard by the courts, it will presumably create more 'out of court' work for lawyers in an already stressed and generally under resourced field.

However, there may be tactical measures that lawyers can employ when considering the advice they give to clients about bail applications. This arises when looking at the difference between a bail application and a bail review. Section 22A states:

(3) The Supreme Court may refuse to entertain a bail application in relation to bail if the bail application comprises a bail condition review that could be dealt with under section 48A by a magistrate or authorised justice or the District Court.

(4) Except as provided by subsection (3), this section does not affect the power of a court to review a decision in relation to bail under Division 2 of Part 6 or the right of a person to request such a review.

Andrew Haesler SC states that 'there are two opposing views about the distinction between "application" and "review" (Haesler 2008). The first view is based on the definition of bail in $54^{6}$ whereby a person can only make an application for bail if they do not already have it. A person refused bail would have to make a fresh application because they are requesting to be at liberty. A review is only necessary if bail has been granted, thus confining s22A to a narrow interpretation and severely restricting an accused's ability to re-apply for bail. In this situation it may be tactically advantageous for some accused people to represent themselves in their first bail application, so that, if unsuccessful, they could apply again with legal representation. This, however, would defeat the purpose of the amendment to improve the efficiency of the criminal justice system, and would shift the perceived problem from 'magistrate shopping' to 'try before you buy'.

The alternate view, as stated and advocated for by Mr Haesler, is that bail reviews are not confined to those already granted bail, but extend to those who have been denied bail. $\mathrm{Mr}$ Haesler points to several sections in the Bail Act to support his view, notably s44(2) where 'a magistrate may review any decision ... in relation to bail' and s45(1) where 'the Supreme Court may review any decision ... in relation to bail'. Further, Mr Haesler points to s22A(4) itself, which clearly stipulates that a court's power to review is not affected by the section. Thus, any decision about bail may be reviewed, and as Mr Haesler points out, the section's 'negative consequences would be considerably reduced' (2008); s22A would only prevent fresh applications where bail has been refused but would allow that person to apply for a review. This is advantageous because it means an accused can be represented throughout the bail process and reviews of bail decisions are de novo pursuant to s48(3) of the Bail Act. However, this interpretation is not consistent with the object of the amendment, and it will circumvent the purpose of the policy as s22A does not restrict the number of applications for review of bail that can be made.

\section{Crime Victims and Penal Policy}

Given its punitive nature and adverse repercussions, s22A is not a benign amendment to the Bail Act. It represents a significant reconfiguration of the ancient institution of bail in our criminal justice system. In limiting the number of bail applications that an accused can make to a court without an empirical or otherwise rational justification, s22A appears to breach long-standing adherence to fundamental principles of criminal justice - the presumption of innocence and concomitant entitlements to release and liberty. How then has the NSW 
Government come to enact law with the potential for such deleterious repercussions on unconvicted people?

On its face, s22A is not explicable as being necessary to protect specific persons or groups of persons, the community and nor is it necessary, aside from the claim of 'magistrate shopping' to promote the effective administration of criminal justice. Rather, according to the Attorney-General, the ultimate purpose of these provisions is to 'guard against repetitive bail applications that have no chance of success and can greatly disturb the victim and induce worry and anxiety at the prospect of the defendant's release' (NSW Legislative Council 2007:2669). Significantly, at no stage during his reading speech does the Attorney-General refer to the accused's entitlement to liberty, the presumption of innocence or the adverse consequences of being held on remand.

A striking feature of this amendment is that it is not presented as a rational argument for penal change on the basis of efficiency of the criminal justice system or the need to protect the community, or particular crime victims, from the risk of potential harm. Instead, in seeking to relieve crime victims from the 'anxiety' and 'worry' at the 'prospects of the defendant's release' generated by repeated bail applications at the expense of the entitlement of an unconvicted person to bail, government policy reveals new priorities and objectives, the feelings of crime victims, to guide bail as a penal practice.

The post-war decades have witnessed enormous change in the status of the victim of crime in criminal justice and the role of the victim in the development of penal policies from 'outsider par excellence' (Ryan 2003), to becoming 'the centre of contemporary discourse' (Garland 2001). Certainly during the last two decades in particular, the crime victim has achieved such remarkable political and penal prominence that it is not at all surprising that the impetus for such significant reconfiguration of the bail laws was the immediate personal interests of victims of crime. As Garland argues, in our current political climate the crime victim is 'a righteous figure whose suffering must be expressed and whose security must be guaranteed' (2001:11).

As a result of the political imperative to be responsive to victims' feelings and concerns, a distinctive feature of punitive crime policies is the privileged place that is afforded to crime victims at the expense of the perceived criminals, in our case the accused (Garland 2001:143). Therefore, in an attempt to relieve the 'anguish' and 'worry' of crime victims, bail is reconfigured as if crime policy was a zero-sum game where the promotion of the interests of crime victims requires the reduction of accused people's entitlements. As the previous law stood, the accused's entitlement (almost unlimited number of bail applications in relation to an offence) was the victim's loss (anxiety and worry that the same application could be made time and again). Under the new s22A, the crime victims' gain (restriction of the number of bail applications that can be made in relation to an offence) is the accused person's loss (severe curtailment of the number of bail applications that can be made to a court and an increased likelihood of remand).

Section 22A has two significant premises. The first premise is that this provision is necessary to assuage particular concerns of victims of crime with respect to bail. Second, that accused people mercilessly exploit bail processes. With regard to the first premise, the government is mistaken in treating crime victims as if there was such a homogenous group whose members want and need the same response from the law. The government's crime victim is a political, symbolic creature - representative of all suffering associated with crime - whose experience is 'assumed to be common and collective' (Garland 2001:144). Research has demonstrated, however, that heterogeneity of the experiences of crime victims 
is the reality, a view that belies the one-size-fits-all approach of this legislation. The push for victims' rights has been on the Australian political agenda since the 1980s and it has generally been propelled by or on behalf of victims of serious crimes of violence (Richards 2006:1.3.1). As Richards has observed, we usually hear of the plight of crime victims in the criminal justice system from victims or family victims of offences such as murder, manslaughter, driving offences causing death and sexual offences (1.3.1). On the other hand, research studies have shown that victims of minor or property offences often do not want to become involved in the criminal justice system or just want to be provided with relevant information and kept up to date (Gardner 1990:49-50; see also Cook et al. 1999; Hoyle et al. 1998).

The majority of criminal charges that come before the local court (and which would most likely involve questions of bail) are generally concerned with crimes other than those involving serious violence (NSW Bureau of Crime Statistics and Research 2007). ${ }^{7}$ It is also noteworthy that the majority of crimes committed by juveniles are what can be characterised as minor or property offences such as theft and graffiti (Cunneen \& White 2002:67). Thus, the anguish of victims generated by bail applications referred to by the Attorney-General is arguably only an issue to a small group of victims of serious crimes of violence.

Even with respect to those crime victims that do experience the worry described by the Attorney-General in relation to bail applications, it is difficult to see how s22A will alleviate these concerns. Crime for many victims is a devastating experience and there is no doubt that some crime victims will be distressed and anxious about the outcome of bail applications. Many crime victims do not want the relevant accused to be at liberty and it is just as certain that accused persons do not want to be incarcerated. Given the disparity of their positions, it seems impossible to reconcile the conflicting interests of many crime victims and accused persons on this issue. The point of responsible law-making, however, is to try to balance such divergent interests against accepted legal principles and traditions. Through the criteria in s32 and the wide range of conditions that may be imposed under the Act, the law already seeks to balance the concerns of the crime victim against the interests of the unconvicted accused. The government does not refer to research that indicates these provisions of the Act are inadequate. Instead of provisions such as s22A, the government should improve, if necessary, the availability of support and information for crime victims and maintain the integrity of our criminal justice system that is based on the presumption of innocence and entitlement to liberty.

As to the second premise, the accused is depicted as one exploiting the existing system using the practice of 'magistrate shopping' and 'access to money' to make 'repetitive bail applications that have no chance of success' but again there is no evidence to support these claims. For example, in Victoria, there is a Magistrates Court practice direction that future bail applications will be heard by the same magistrate if possible (Magistrates Court of Victoria, Practice Direction No 1 of 2004). According to the VLRC this direction helps ensure that one magistrate can control the process and prevent any abuse of the court process if the accused makes repeat in-person applications. The VLRC noted that the

The NSW Bureau of Crime Statistics and Research does not publish bail statistics of bail status by charge however the 2006 NSW criminal court statistics reveal that the most frequently charged offences are: acts intended to cause injury (but non-aggravated assault), road and traffic offences (exceed PCA), driving while licence cancelled, suspended or disqualified and driving without a licence. From these court statistics we derive the view that the majority of criminal matters that come before the courts do not involve crimes of serious violence. 
magistrates they consulted said that the 'in-person' bail application process is not generally abused as they can control the hearing. There is no reason why a similar direction could not be introduced in NSW and thus deal with the issue of abuse of process without the need to legislate away peoples' rights.

Furthermore, the image of the 'cashed up' accused person runs counter to the profile of NSW prisoners. The Attorney-General offered no evidence to indicate that the problem of magistrate shopping exists, or even the extent of the problem in his second reading speech. The insinuation is that the problem is prevalent. In fact the evidence suggests that this is a tenuous claim and that people in prison are among the most poor and marginalised people in the community.

In 2007 the Australian Institute of Criminology collated selected offender profiles and found, in relation to the characteristics of adult police detainees, that $34 \%$ of male and $47 \%$ of female detainees received welfare or government benefits as their main source of income (Dearden \& Bricknell 2007:67). Additionally, 6\% of male and 5\% of female detainees had experienced homelessness in the month prior to their arrest (Dearden \& Bricknell 2007:69).

The NSW Corrections Health Service found that the prevalence of 'any psychiatric disorder' in the NSW inmate population was 74\%, a percentage substantially higher than that found in the general community namely 22\% (Butler \& Allnut 2003:2). Further, in the 2001 NSW Inmate Health Survey, 11\% of women and $20 \%$ of men were identified as problem or pathological gamblers, and $18 \%$ of women and $27 \%$ of men scored below the pass rate on the intellectual disability screener (Butler \& Milner 2003:8).

The NSW Department of Juvenile Justice recognises that young people in custody 'are characterised by disadvantaged backgrounds' (NSW Department of Juvenile Justice 2003:10). Of the 242 young people surveyed in 2003, $43 \%$ stated that one or more of their parents had been imprisoned and $11 \%$ had a parent who was currently imprisoned, $17 \%$ had cognitive functioning scores consistent with intellectual disability, and $88 \%$ reported varying degrees of symptoms consistent with a clinical disorder (NSW Department of Juvenile Justice 2003:9).

These statistics demonstrate only some of the issues pertaining to people in contact with the criminal justice system. It does not reflect accused persons being 'cashed up' and equipped to manipulate the system. The image of the 'cashed up' accused is also somewhat ironic, given that a major reason for reforming the bail laws in the late 1970s was the inequity of bail system largely based on the deposit of money or a surety to forfeit a sum of money if bail was breached (NSW Bureau of Crime Statistics and Research 1984:3). It is by no means clear what the government has relied on to justify these restrictive and detrimental changes in relation to bail. The legitimacy of the government's policy to prevent 'magistrate shopping' and to alleviate the anxiety of victims is questionable in light of a lack of measuring and monitoring, lack of reliance on the best available empirical evidence and an apparent lack of commitment to evaluate the policy. According to Weatherburn:

[The] first steps a responsible politician or public servant will take is to conduct or commission a search of the relevant literature to see what factors influence the kind of crime problem, what strategies or tactics have been employed in tackling what the research tells us about their success or failure (2004:37).

That has not happened here. 


\section{Conclusion}

The current amendment to s22A of the Bail Act can be characterised as a punitive crime policy. Bail has clearly been reconfigured to demote the interests of an accused's right to be at liberty until proven guilty, and to promote factors such as the improved administration of justice and the concerns of victims of crime. This is not to say that these concerns are not important. The point is that the government could be exploring alternative ways to balance these interests. We have suggested two possible alternatives, namely improved support and information for crime victims, and/or an increase in the range of bail conditions so as to alleviate the potential anxiety of certain victims.

The reconfiguration of bail demonstrates a move away from the primary purposes of remand to ensure that the accused will appear in court, will not commit further offences, and will not interfere with witnesses or victims or endanger the safety and welfare of the community. We agree with King et al. (2008) that custodial remand is now being used as a tool for punishment and to promote law and order policies such as being tough on crime and criminals. The increase in the remand population is cited by the government as proof that the changes to the Bail Act are delivering results. This may be an effective measure of success in relation to removing the presumption in favour of bail for specific offences or offenders, but it is not a satisfactory or reliable measure in relation to whether the amendment to s22A will prevent magistrate shopping or whether it will alleviate the anxiety of victims of crime over the accused's release. Moreover, comprehensive and timely research in this area has not been conducted since the introduction of the Bail Act in the late $1970 \mathrm{~s}$. There is no evidence to suggest that there are any, let alone a small number of people, who are 'cashed up' and 'magistrate shopping'. In light of the evidence of the detrimental effects of being held on remand, it is difficult to conclude that these reforms are anything other than punitive law and order policy.

\section{References}

Australian Bureau of Statistics 2007 Prisoners in Australia, 2007: Summary of Findings $<$ http:www.abs.gov.au> accessed 31 March 2008

Brignell G 2002 'Bail: An Examination of Contemporary Issues' Sentencing Trends and Issues Judicial Commission of New South Wales

Brown D 'Continuity, rupture, or just more of the "volatile and contradictory": Glimpses of New South Wales' Penal Practice behind and through the discursive' in Pratt J, Brown D, Brown M, Hallsworth S \& Morrison W (eds) 2005 The New Punitiveness Willan Publishing Devon UK pp 27-46

Butler T \& Allnut S 2003 Mental Illness Among New South Wales Prisoners NSW Corrections Health Service

Butler T \& Milner L 2003 The 2001 New South Wales Inmate Health Survey NSW Corrections Health Service

Cooke B, David F \& Grant A 1999 Victims' Needs, Victims' Rights: Policies and Programs for Victims of Crime in Australia Australian Institute of Criminology, Research and Public Policy Series No 19 Canberra 
Cunneen C \& White R 2002 Juvenile Justice: Youth and Crime in Australia Oxford University Press Melbourne

Dearden J \& Bricknell S 2007 'Australian Crime Facts and Figures 2007' Australian Institute of Criminology Canberra

Edney R 2007 'Bail conditions as a mitigating factor in sentencing' Criminal Law Journal vol 31 no 2 pp 101-112

Feeley M 1979 The Process is the Punishment: Handling Cases in a Lower Criminal Court Russell Sage Foundation New York

Findlay M, Odgers S \& Yeo S 2005 Australian Criminal Justice 3rd edn Oxford University Press Melbourne

Freiberg A \& Morgan N 2004 'Between Bail and Sentence: The Conflation of Dispositional Options' Current Issues in Criminal Justice vol 15 no 3 pp 220-236

Gardner J 1990 Research Report No 5. Victims and Criminal Justice Office of Crime Statistics South Australian Attorney General's Department

Garland D 2001 The Culture of Control Oxford University Press Oxford

Grabosky P 1999 'Zero Tolerance Policing' Trends and Issues in Crime and Criminal Justice No 102 Australian Institute of Criminology pp 1-4

Haesler A 2008 'New Bail Laws 2008 - s22A Bail Act 1978' Seminar Paper presented to the NSW Criminal Defence Lawyer's Association $<$ www.lawlink.nsw.gov.au/lawlink/pdo/11_pdo.nsf/pages/PDO_newbaillaws2008> accessed 11 June 2008

Hampel G \& Gurvich D 2003 Bail Law in Victoria: a practical guide to the law, procedure and advocacy in bail applications The Federation Press Sydney

Hatzistergos J 2007 'Bail an important part of the justice system' (Sydney) Daily Telegraph 26 July p 27

Hollero M 2007 The Metropolitan Remand and Reception centre: The First Ten Years Statistical Publication No 29 NSW Department of Corrective Services

Hoyle C, Morgan R \& Sanders A 1998 Evaluation of the 'One Stop Shop' and Victims Statement Pilot Projects Report for the Home Office Research Development and Statistics Directorate London

Johns R 2002 'Bail Law and Practice: Recent Developments' Briefing Paper No 15/2002 New South Wales Parliamentary Library Research Service

Joudo J \& Veld M 2005 Deaths in Custody in Australia, Technical and Background Paper series No 19 Australian Institute of Criminology Canberra

Kelkar RV 1998 Lectures on Criminal Procedure 3rd edn Eastern Book Company Lucknow

King S, Bamford D \& Sarre R 2008 'The Remand Strategy: Assessing Outcomes' Current Issues in Criminal Justice vol 13 no 3 pp 327-344

Magistrates Court of Victoria, Practice Direction No 1 of 2004 
New South Wales Bureau of Crime Statistics and Research 1984 Bail Reform in NSW NSW Bureau of Crime Statistics and Research Sydney

New South Wales Bureau of Crime Statistics and Research 2007 New South Wales Criminal Court Statistics 2006 Statistical Services Unit NSW Bureau of Crime Statistics and Research Sydney

New South Wales Department of Juvenile Justice 20032003 NSW Young People in Custody Health Survey: Key Findings Report NSW Department of Juvenile Justice

New South Wales Law Reform Commission 2005 Young Offenders Report 104 New South Wales Law Reform Commission <www.lawlink.nsw.gov.au> accessed 31 March 2008

New South Wales, Legislative Assembly 1989 Bail Amendment Bill 1989 Second Reading Hansard 3 May 1989 p 7328

New South Wales, Legislative Council 2007 Bail Amendment Bill 2007 Second Reading Hansard 17 October 2007 p 2669

Pratt J 2000 'Emotive and Ostentatious Punishment' Punishment and Society vol 2 no 4 pp 417-439

Richards K 2006 "Rewriting history": towards a genealogy of "restorative justice" unpublished $\mathrm{PhD}$ thesis, University of Western Sydney

Ryan M 2003 Penal Policy and Political Culture in England and Wales Waterside Press Winchester

Sarre R, King S \& Bamford D 2006 'Remand in Custody: critical factors and key issues' Trends and Issues in Crime and Criminal Justice No 310 Australian Institute of Criminology Canberra

Simpson R 1997 'Bail in New South Wales' Briefing Paper No 25/97 New South Wales Parliamentary Library Research Service

Victorian Law Reform Commission 2005 Review of the Bail Act: Consultation Paper Melbourne Victorian Government Printer

Victorian Law Reform Commission 2007 Review of the Bail Act: Final Report Melbourne Victorian Government Printer

Weatherburn D 2004 Law and Order in Australia: Rhetoric and Reality The Federation Press Sydney

Weatherburn D, Quinn M \& Rich G 1987 'Drug Charges, Bail Decisions and Absconding' The Australian and New Zealand Journal of Criminology vol 20 no 2 pp 95-109 